pose of raising a tribute to the memory of that great surgeon, and a long and splendid list of subscriptions was once advertised in The Times. I immediately afterwards paid the subscriptions of myself and some friends, but since then I have not seen or heard anything more of the matter. Can you -inform me, Sir, living as I do in the country, whether it is still proposed to carry out the original object, or not. If my memory serves me rightly, the amount subscribed was such as to give every prospect of a sufficiency of funds for the contemplated statue, and I am at a loss to understand why it has not been proceeded with. The non-professional members of the committee may think themselves excused in not taking an active share, (though $I$ believe such is not the case;) but the profession had a right to expect that the teachers of the college in which he was one of the brightest ornaments, would not show the intense apathy they have done, in allowing eighteen months to elapse without stirring themselves to carry out the wishes of the subscribers. I forbear to say more, in the hope that some member of the committee may be able to explain this apparent neglect of so great a man.

May, 1849. Yours in sorrow,

$$
\text { An Ond Pupta of Liston. }
$$

\section{THE FIVE-HUNDRED-POUNDS MEDICAL REFORM FUND.}

To the Editor of 'THE LANCET.

Sir,--It appears essential that the subscribers to the Medical Reform Fund should meet, to arrange a plan of organization, and how to act most effectually for the interest of the profession. Without this, they will do nothing.

The question is-Where to meet? To overcome this diffculty, and as a preliminary movement, I propose to them, and to any member of the profession who feels disposed, to meet at my house, to discuss the subject, on Wednesday, May 30th, at seven P.M. Should this appear feasible and agreeable to members, I shall be obliged by those who will attend writing me a note to that effect, as soon after reading this as convenient. I am, Sir, yours \&c.,

Henry Hanson Dearshy, M.R.C.S. \& L.A.C.

15, Bridge-terrace, Harrow-road, May, 1849.

Dr. Crisp presents his compliments to the Editor of THE IANCET, and begs to add his subscription of $£ 228$. to the ". Medical Reform Fund."

Parliament-street, May, 1849.

\section{MEDICAL FEES AT INSURANCE OFFICES.}

To the Editor of THE LANCET.

Sxr,-Being one of those who think the profession at large greatly indebted to you for your recent notices in regard to Insurance Offices, and that it now only remains for medical men to refuse gratuitous certificates, to induce the publicthe insured-to form a fair estimate of the relative security of those societies, which, on the one hand, obtain the valuable certificate, by equitable payment, and use it-or, on the other, insure the life on the single interview with their own referee, because they will not pay for better information; I beg to send you a correspondence with the Secretary of the Provident Clerks'Association; and have the honour to be, Sir, your obedient servant, Chirurgus.

\section{To the Secretary of the Provident Clerks' A ssociation.} Exeter, March 22.

StR,-I have received from your agent the usual form of application relative to the health of Mr. - , but without any fee or intimation that I was to look for one from your Office. I shall not trouble you at length with my observations, as you must be familiar with the principle the profession is so rapidly establishing; but I will merely add, it is no sordid motive which induces me to decline giving this or any other certificate; and that under the circumstances of your particular Society, I am of opinion that a small honorarium would meet the requirements of the principle. With every wish for the success of your institution, I have the honour to be, \&c. \&c.

Provident Clerks' Association, March 24, 1849. SIR, - I have received your esteemed favour, and thank you for the kind wishes you have expressed for the prosperity of this Association. Our directors admit, that in all cases of assurance a fee should be given for the medical report, thereby paying the proper tribute to the faculty; but they do not consider they ought to pay for that information which the person proposing to insure his life is bound to furnish. In all towns where we have an agency, a medical referec is appointed, who is paid for every person whom lie examines; but the board of management has always declined to remunerate the medical adviser of the party wishing to effect an insurance with this Office.-Yours \&c.

To - - Esq., Surgeon, Exeter.

P. N. Bynne, Secretary.

Exeter, March 25.

Sin,-I am in receipt of your polite note, which you must be fully aware blinks the question the profession is determined to raise. I can only refer you, in your assumed ignorance of the question at issue, to recent leaders in TrE LANCET, where you will see the names of those Societies which the profession is bound to support; and beg you to advise your Exeter agent to submit Mr. - 's application at once to your referee, if you think such course calculated to benefit your Association. If, on the other hand, you seek to make mischief between myself and my patient, then a course of open hostility is all that is left me in self-defence.

To the secretary \&c.

Yours \&c.

(The application, I am given to understand, was accepted.)

\section{MEDICAL CLUBS IN THE ISLE OF WIGHT, To the Editor of THE LaNCET.}

I am sorry to say that I am a witness to a disgraceful system of medical club-practice. There is a medical man residing in Newport, Isle of Wight, who has now been in practice about six years. When he first left the hospital, and before any one could possibly judge of his professional acquirements, he instantly, in the face of all the medical men of the town, started these cheap medical clubs, which are nearly a dozen in number. One would suppose the patients valued their money more than their lives. I am not alluding to want of skill on the part of the "club doctor," but the utter impossibility, even with an assistant, to give them that attendance they stand in need of. There is scarcely a farmer or tradesman who is not in these three-shilling (per year) clubs. There are fourteen or fifteen medical men in Newport who, as I have stated before, had these, now " club people," once as their private patients, making a difference of some hundreds of pounds less in their receipts per annum. If the clubs had been limited to the labouring classes, earning from ten to twelve shillings per week, who would not be entitled to any allowance from the parish in illness, and yet are not able to pay a medical bill, it would have been no more than fair, but in this instance the large farmers and respectable tradesmen of the neighbourhood have most disgracefully joined. One would suppose education, time, and knowledge, of little value, if it can be afforded to retail them all out at so cheap a rate. I an of opinion that all similar cases should be made public in your valuable journal.

I am, Sir, your obedient servant,

Newport, Isle of Wight, 1849 . ONe OF the MaNy InJURED.

\section{A CASE FOR A COURT-MEDICAL.}

To the Editor of Thu LaNceT.

Sir,--Feeling assured of your impartiality as a judge on the conduct of professional men towards each other, I take the liberty of troubling you with an account of the treatment I have lately experienced from a brother practitioner, whom I should have expected to set an example of etiquette and strict professional conduct, instead of adding personal insult to a breach of both these, under which I cannot remain silent. I will therefore state particulars, and leave you, and the readers of your widely-circulated journal, to decide.

I attended Mrs. - in her confinement, on Saturday, Feb. 17th, 1849. She was progressing very favourably, up to Feb. 24 th, when she was attacked with pleurisy of the right side, and subacute inflammation of the large lobe of liver. Notwithstanding the active treatment employed, effusion took place in the right pleura. The husband became alarmed, and he asked me if I had any objection to meet another medical man, to which I replied, that I would meet any one he might wish. W. Birch, Esq., a highly-respected and able practitioner, residing at Barton-under-Needwood, was accordingly sent for, on Monday, March 5th, and arrived early the follow. ing morning. Mr. Birch confirmed my opinion of the case, and ordercd the treatment I was adopting to be persevered in. On this day, March 6 th, I heard accidentally that Mr. Chapman, a gentleman practising in this town, had seen my patient 